(International Journal of Agriculture and Wildlife Science)
http://dergipark.org.tr/ijaws

Araştırma Makalesi

\title{
Ağrı-Eleşkirt Koşullarında Yazlık Olarak Farklı Zamanlarda Ekilen Yem Bezelyesi Çeşitlerinin Ot Verimi ve Bazı Kalite Özelliklerinin Belirlenmesi ${ }^{* *}$
}

\author{
Süleyman Temel ${ }^{1 *}$ iD, Emrah Yazıcı ${ }^{2}$ \\ ${ }^{1}$ Iğdır Üniversitesi Ziraat Fakültesi Tarla Bitkileri Bölümü, Iğdır \\ ${ }^{2}$ Eleşkirt İlçe Tarım ve Orman Müdürlüğü, Ağrı
}

Geliş tarihi (Received): 24.04.2021 Kabul tarihi (Accepted): 02.06.2021

\section{Anahtar kelimeler:}

Çeşit adaptasyonu, ekim dönemleri, kaba yem üretimi, yem kalitesi.

Özet. Hayvancılığın yoğun olarak yapıldığı Ağrı-Eleşkirt'te yüksek yem kalitesine sahip yem bezelyesinin ekim alanı ve bu bitki ile ilgili yürütülmüş bir bilimsel çalışma bulunmamaktadır. Dolayısıyla bölgede yem bezelyesi tarımının yaygınlaştıııması için çeşit adaptasyonu ve ekim zamanı gibi temel agronomik çalışmaların tamamlanması önem arz etmektedir. Mevcut çalışma ile Ağrı-Eleşkirt koşullarında uygun yem bezelyesi (Pisum sativum ssp. arvense L.) çeşitleri ve ekim zamanlarının belirlenmesi amaçlanmıştır. Bu amaçla Özkaynak, Taşkent, Kirazlı ve Ürünlü çeşitleri 15'er gün aralıklarla (Nisan başı, Nisan sonu ve Mayıs başı) ekilerek çiçeklenmeye başlama tarihi, bitki boyu, bitki başına dal sayısı, ana sap kalınığı, kuru madde oranı, yaş ve kuru ot verimi ile kalite özellikleri (ham protein oranı, NDF ve ADF oranı) değerlendirilmiştir. Deneme, 2018 yılında sulu koşullarda tesadüf bloklarında bölünmüş parseller deneme desenine göre üç tekrarlamalı olarak kurulmuştur. Analiz sonucu incelenen parametreler üzerine ekim zamanı (kuru madde oranı hariç) ve çeşitlerin (bitki boyu, dal sayısı, NDF ve ADF oranı hariç) etkisi önemli bulunmuştur. Bu sonuçlara göre, en yüksek ham protein içeriği, yaş ot ve kuru ot verimleri ile en düşük NDF ve ADF oranları Nisan başında yapılan ekimlerde belirlenmiştir. Ayrıca yüksek verim ve kaliteye sahip ot üretimi için Taşkent ve Ürünlü çeşitlerinin bölge ekolojisine uygun olduğuna karar verilmiştir.

*Sorumlu yazar stemel33@hotmail.com
\end{abstract}

\section{Determination of Herbage Yield and Some Quality Characteristics of Forage Pea Varieties Sown at Different Times as Summer in Ağrı-Eleşkirt Conditions}

\section{Keywords:}

Variety adaptation, sowing dates, roughage production, forage quality.

\begin{abstract}
In Ağrı-Eleşkirt, where animal husbandry was intensely carried out, there is no scientific study and cultivation area for forage pea with high feed quality. Therefore, it is important to complete the basic agronomic studies such as variety adaptation and sowing time in order to popularize the forage pea agriculture in the region. With the present study, it was aimed to determine the suitable forage pea (Pisum sativum ssp. arvense L.) varieties and sowing dates in Ağrı-Eleşkirt conditions. For this purpose, Özkaynak, Taşkent, Kirazlı and Ürünlü varieties were sown at 15-day intervals (beginning of April, end of April and beginning of May) and evaluated in terms of herbage yield (beginning of flowering, plant height, number of branches per plant, stem thickness, dry matter ratio, fresh and dry herbage yield) and quality characteristics (crude protein ratio, NDF and ADF ratio). The experiment was established according to a split plot in randomized block design with three replicates under irrigated conditions in 2018. As a result of the statistical analysis, the effect of sowing date (except for the dry matter ratio) and varieties (except for the plant height, number of branches per plant, NDF and ADF ratio) on the examined parameters was found to be significant. According to these results, the highest crude protein content, fresh and dry herbage yields and the lowest NDF and ADF ratios were determined in the sowings made in the beginning of April. In addition, it has been decided that Ürünlü and Taşkent varieties would be suitable for the ecology of the region for roughage production with high yield and quality.
\end{abstract}




\section{GíRiş}

Karlı bir hayvancılık için hayvanlara yedirilen yemin ucuza mal edilmesi gerekmektedir. Ucuz yem kaynağı olarak da çayır-mera alanlarından temin edilen veya tarla ziraatı içerisinde üretilen kaba yemler, hayvan besleme açısından önemli bir yer tutmaktadır. Bu anlamda ülkemizde yaygın olarak yetiştiriciliği yapılan yonca, korunga ve fiğ gibi baklagil türleri ile çim, mısır ve sorgum gibi buğdaygil türleri önemli kaliteli kaba yem kaynaklarının başında gelmektedir (Tan ve Temel, 2012; Tan, 2018). Ayrıca son yıllarda Devlet tarafından yapılan desteklemelerle yem bitkisi türlerinin çeşitliliğinde ve ekim alanlarında önemli artışlar olmuştur (TÜiK, 2021). Bu türlerden bir tanesi de yüksek kalitede yem materyali (ot, tohum ve kes) üretebilen ve hayvanlar tarafından sevilerek tüketilen yem bezelyesi (Pisum sativum ssp. arvense L.) türüdür (Tekeli ve Ateş, 2007; Göçmen ve Özaslan Parlak, 2017; Keskin ve ark., 2021). Nitekim ülkemizde yem bezelyesi tarımı son beş yılda önemli oranda artış göstererek, 2018 yılı itibariyle 104.377 dekarlık bir ekim alanına ulaşmıştır (TÜiK, 2020). Ancak diğer yem bitkisi türlerinde olduğu gibi yem bezelyesi türünde de tarla ziraatı içerisindeki ekim alanları arzu edilen seviyelere ulaşamamıştır. Bunda bölgelere göre uygun yem bitkisi tür ve çeşitlerinin geliştirilmemiş olması, bu türlerle ilgili tohumluk problemlerin yaşanması ve bölgelere göre uygun ekim zamanı ve çeşit adaptasyonu gibi temel bazı agronomik çalışmaların tamamlanmamış olmasının büyük bir etkisi bulunmaktadır (Tan, 2018).

Doğu Anadolu Bölgesinde yer alan Ağrı ilinde topoğrafik yapı ve karasal iklim özelliğinden dolayı çayır-mera alanları önemli bir yer tutmakta (TÜiK, 2021) ve bu nedenle bölgede hayvancılık yoğun bir şekilde yapılmaktadır. Çünkü çayır-mera alanları hayvanların beslenmesinde önemli bir girdi olan kaba yem temininde önemli bir kaynak durumundadır. Ayrıca bölgede vejetasyon süresinin kısa olması nedeniyle yetiştirilebilecek ürün çeşitliliği kısıtlı olup, halk geçimini bitkisel üretimden ziyade hayvancılık yaparak sağlamaktadır. Ancak bölgenin hayvan sayısı dikkate alındığında çayır-mera alanlarından elde edilen kaba yem miktarı, hayvanların dengeli beslenmesi için yeterli bulunmamaktadır. Bu nedenle bölge çiftçisinin tarla tarımı içerisinde yonca, korunga ve fiğ gibi yem bitkisi türlerinin yetiştiriciliğine yoğun bir şekilde yer verdikleri görülmüştür. Ancak düşük sıcaklıklara dayanabilen, yüksek ot ve tane kalitesine sahip yem bezelyesi türünün bölgede yetiştiriciliğinin yapılmadığı ve bu nedenle yem bezelyesi türünün alternatif yem kaynağı olarak bölge için bir avantaj olabileceği düşünülmektedir.

Geniş bir adaptasyon yeteneğine sahip olan yem bezelyesi baklagil familyası içerisinde yer alan tek yıllık bir türdür. Tam çiçeklenme döneminde biçilen otu \%20 civarında ham protein içerebilmektedir (Tekeli ve Ateş, 2007). Yine toprak, iklim ve uygulanan kültürel koşullara bağlı olarak dekara 250-1000 kg arasında kuru ot üretebilmektedir (Tekeli ve Ateş, 2007; Sheaffer ve Moncada, 2012; Tan ve ark., 2013; Alatürk ve ark., 2021; Temel ve ark., 2021). Ancak yüksek miktar ve kalitede ot üretimlerinin elde edilebilmesi için öncelikle bölge ekolojisine uygun çeşit adaptasyon çalışmalarının tamamlanması gerekmektedir. Çünkü farklı ekotiplerden orijinlenen ve ıslah çalışmalarıyla geliştirilen çeşitler farklı genetik yapıya sahip olmakta ve ortam koşullarına farklı tepki gösterebilmektedirler. Bu nedenle de birim alandan elde edilen verim ve kalite performansları farklılık gösterebilmektedir. Nitekim farklı coğrafyalarda öncesinde yapılan çalışmalarda ot verim ve kalite özelliklerinin çeşitler arasında farklılık gösterdiği ortaya konmuştur (Timurağaoğlu ve ark., 2004; Açıkgöz ve ark., 2007; Çil ve ark., 2007; Sayar ve ark., 2009; Geren ve Alan, 2012; Uzun ve ark., 2012; Seydoşoğlu, 2013; Tan ve ark., 2013; Kadıoğlu ve Tan, 2018; Temel ve ark., 2021). Ayrıca birim alandan elde edilen otun verim ve kalitesini optimize etmek için bölge koşullarına göre uygun ekim tarihlerinin belirlenmesi gerekmektedir. Bu amaçla farklı coğrafik bölgelerde uygun ekim zamanlarının belirlenmesine yönelik çok sayıda araştırma yürütülmüş, verim ve kalite değerleri üzerine ekim zamanlarının önemli etkisinin olduğu belirtilmiştir (Gündoğdu, 2006; Shaukat ve ark., 2012; Mukherjee ve ark., 2013; Ton, 2013; Kadıoğlu ve Tan, 2018; Konuk ve Tamkoç, 2018; Temel ve ark., 2021). Ancak hayvancılığın yoğun olarak yapıldığı Ağrı (Eleşkirt)'da ot verim ve kalite özellikleri üzerine farklı yem bezelyesi çeşitleri ve ekim zamanlarının etkisini ortaya koyan herhangi bir çalışma bulunmamaktadır.

Yürütülen bu çalışma ile 4 yem bezelyesi çeşidi ve 3 farklı ekim zamanı incelemeye alınmış ve incelenen özellikler (bazı verim ve kalite parametreleri) açısından bölge için uygun yem bezelyesi çeşitleri ve ekim zamanlarının belirlenmesi amaçlanmıştır.

\section{MATERYAL VE METOT}

\section{Materyal}

Çalışma 2018 yılında $1860 \mathrm{~m}$ rakıma sahip Ağrı ili Eleşkirt Ovasında $\left(42^{\circ} 37^{\prime}-43^{\circ} 00^{\prime}\right.$ doğu boylamı ile $39^{\circ} 42^{\prime}$ $39^{\circ} 45^{\prime}$ kuzey enlemleri) yürütülmüştür. Bölge karasal iklim özelliğine sahip olup yetişme süresi boyunca araştırma sahasının uzun yıllar ve 2018 yılına ait bazı iklim değerleri Çizelge 1'de sunulmuştur. Çizelge 1 incelendiğinde, uzun yıllar ortalamasına göre ortalama sıcaklık, nispi nem ve toplam yağış miktarları sırayla $15.3{ }^{\circ} \mathrm{C}$, \%60 ve 219.1 mm, olarak kaydedilmiştir. Denemenin yürütüldüğü 2018 yılı Nisan-Ağustos aylarına ait toplam yağış miktarı ise 
$218.4 \mathrm{~mm}$, ortalama sıcaklık $16.8^{\circ} \mathrm{C}$ ve nispi nem değeri \%57.8 olarak ölçülmüştür (MGM, 2019). Deneme alanının bazı toprak özelliklerini belirlemek için 0-30 cm derinliğinde ekim öncesi yeter miktarda toprak örnekleri alınmış ve analizler Ağrı illi Merkez Toprak Analiz Laboratuvarında yaptııılmıştır. Analiz sonucu deneme sahası topraklarının; killi-tınlı yapıda, tuzsuz (\%0.03), hafif alkali karakterde $(\mathrm{pH} 7.6)$, organik madde (\%1.41) ve kireç içeriği (\%0.77) düşük, yarayışlı potasyum içeriği yüksek (111.5 kg K2O da-1 $)$, fosfor içeriği ise orta $\left(7.85 \mathrm{~kg} \mathrm{P}_{2} \mathrm{O}_{5} \mathrm{da}\right.$ 1) seviyede olduğu belirlenmiştir (Kacar, 2012).

Çizelge 1. Araştırma sahasının uzun yıllar (1940- 2017) ve 2018 yılı yetişme sezonuna ait bazı iklim özellikleri*. Table 1. Some climatic characteristics of the study region for long years and the growing season of 2018*.

\begin{tabular}{lcccccc}
\hline \multirow{2}{*}{ Aylar } & \multicolumn{2}{c}{ Yağış miktarı (mm) } & \multicolumn{2}{c}{ Ortalama sıcaklık $\left.\mathbf{~}^{\circ} \mathbf{C}\right)$} & \multicolumn{2}{c}{ Ortalama nispi nem (\%) } \\
& UYO** & $\mathbf{2 0 1 8}$ & UYO & $\mathbf{2 0 1 8}$ & UYO & $\mathbf{2 0 1 8}$ \\
\hline Nisan & 70.3 & 30.2 & 5.9 & 9.0 & 71.7 & 57.3 \\
Mayıs & 70.3 & 95.2 & 11.9 & 12.5 & 65.7 & 74.5 \\
Haziran & 44.1 & 71.7 & 16.4 & 17.0 & 59.7 & 66.1 \\
Temmuz & 21.5 & 8.1 & 21.0 & 23.1 & 53.3 & 44.4 \\
Ağustos & 12.9 & 13.2 & 21.2 & 22.6 & 49.4 & 46.8 \\
\hline Toplam/Ortalama & 219.1 & 218.4 & 15.3 & 16.8 & 60.0 & 57.8 \\
\hline
\end{tabular}

*MGM: 2018, **, Uzun yıllar ortalaması

\section{Metot}

Araştırmada ülkemizde tescil edilen 4 yem bezelyesi çeşidi (Taşkent, Özkaynak, Ürünlü ve Kirazlı) ve 3 farklı ekim zamanı (ED $; 5$ Nisan, $\mathrm{ED}_{2} ; 21$ Nisan ve $\mathrm{ED}_{3} ; 6$ Mayıs) faktör olarak yer almıştır. Gübre materyali olarak da, \%21'lik amonyum sülfat ve \%39-42'lik triplesüperfosfat gübreleri tercih edilmiştir. Çalışma 2018 yılı bahar döneminde sulu koşullarda Tesadüf Bloklarında Bölünmüş Parseller deneme desenine göre üç tekerrürlü olarak kurulmuştur. Ekim zamanları ana parsellere, çeşitler ise alt parsellere yerleştirilmiştir. Ekim dönemleri arasında 15 günlük bir zaman diliminin olmasına özen gösterilmiştir. Denemede toplam 36 parsel yer almış ve her bir parselin alanı (uzunluğu $5.0 \mathrm{~m}$ x genişliği $1.75 \mathrm{~m}$ ) $8.75 \mathrm{~m}^{2}$ olarak planlanmıştır. Ana parseller arasında $2.0 \mathrm{~m}$, alt parseller arasında $1.25 \mathrm{~m}$ ve bloklar arasında ise $1.5 \mathrm{~m}$ boşluk bırakılmış ve toplam araştırma alanı $652.5 \mathrm{~m}^{2}$ (uzunluk 36.25 $\mathrm{m} \times$ en $18.0 \mathrm{~m}$ ) olmuştur. Ekimler $35 \mathrm{~cm}$ sıra aralığında 5 sıra olacak şekilde yapılmış ve dekara $12 \mathrm{~kg}$ tohumluk kullanılmıştır (Geren ve Alan, 2012). Tohum yatağı ve parselizasyon işlemlerinden sonra her ekim döneminde dekara $4.0 \mathrm{~kg}$ saf $\mathrm{N}$ ve $12 \mathrm{~kg}$ saf $\mathrm{P}_{2} \mathrm{O}_{5}$ gelecek şekilde gübreleme işlemleri yapılmış ve toprağa karıştırılmıştır (Ateş ve Tekeli, 2017). Her ekim döneminde tohumlar, toprağın tavda olduğu dönemde markörle $4.0 \mathrm{~cm}$ derinliğinde açılan çizilere elle yapılmış ve üzerleri bastırılmıştır (Geren ve Alan, 2012). Bitkiler toprak yüzeyine çıktıktan sonra ihtiyaç duyduğu dönemde (yaprakların pörsümeye başladığı vakit) yeter miktarda su, salma sulama yöntemi ile karşılanmıştır. Parsel, blok ve sıra aralarında oluşan yabancı otlar ise elle çapalama ve çekme yöntemi ile kontrol altına alınmıştır. Son aşamada bitkiler biçim olgunluğuna geldiğinde kenarlardan birer sıra ve başlardan da 0.5 m'lik kısımlar kenar tesiri olarak atılmış ve geriye kalan kısımlarda örnekleme ve ölçüm işlemleri yapılmıştır. Hasatlar bitkilerdeki alt baklaların tam şeklini aldığı, ancak tane doldurmaya henüz başladığı dönemde orak vasıtasıyla toprak seviyesinden biçilerek gerçekleştirilmiştir (Açıkgöz ve ark., 2007). Parseldeki bitkilerin ekim tarihi ile \%10'nun çiçeklendiği tarih arasında geçen gün sayısı çiçeklenmeye başlama zamanı olarak alınmıştır (Açıkgöz ve ark., 2007). Hasat dönemine gelen parsellerde hasat öncesi hasat alanı içinde kalan kısımda tesadüfen 10 bitki seçilerek, bitkilerin $\mathrm{cm}$ cinsinden boyu (Sarıçiçek, 1995), dijital kumpasla mm cinsinden ana sap kalınlıkları ve bitki başına dal sayıları ölçülmüştür (Tan ve ark., 2013). Daha sonra parsel kenarlarından birer sıra ve başlardan da 0.5 m'lik kısımlar kenar tesiri olarak atılmış ve geriye kalan $4.2 \mathrm{~m}^{2}$ 'lik kısım biçilerek bitkilerin yaş ot verimleri ( $\mathrm{kg}$ da$\left.{ }^{1}\right)$, kuru madde oranları (\%) ve kuru ot verimleri ( $\mathrm{kg} \mathrm{da}^{-1}$ ) Açıkgöz ve ark. (2007) ve Timurağaoğlu ve ark. (2004) tarafından geliştirilen yöntemler kullanılarak belirlenmiştir. Son aşamada ise kurutulup öğütülen yem örneklerinde Mikro Kjeldahl metoduna göre belirlenen toplam \%N oranları 6.25 katsayısı ile çarpılarak ham protein oranı (AOAC, 1997), Van Soest ve ark. (1991) tarafından geliştirilen yöntem kullanılarak da asit çözücülerde çözünemeyen lif (ADF) ve nötr çözücülerde çözünemeyen lif (NDF) oranları belirlenmiştir.

Çalışma sonucunda elde edilen veriler JMP 5.0.1 istatistik paket programında tesadüf bloklarında bölünmüş parseller deneme desenine göre varyans analizine tabi tutulmuş ve önemli çıkan ortalamaların gruplandırılması LSD testine göre yapılmıştır. 


\section{BULGULAR VE TARTIŞMA}

\section{Çiçeklenmeye Başlama Zamanı (gün) ve Bitki Boyu(cm)}

Farklı dönemlerde ekilen yem bezelyesi çeşitlerinin çiçeklenmeye başlama zamanları ve bitki boylarına ait LSD değerleri, önemlilik düzeyleri ve ortalama değerler Çizelge 2'de sunulmuştur. Çizelge 2 incelendiğinde, ekim zamanları açısından çiçeklenmeye başlama zamanları farklılık göstermiş ve 89.8 gün ile en geç çiçeklenme ilk ekim zamanında, 71.1 gün ile en erken çiçeklenme ise son ekim döneminde tespit edilmiştir (Çizelge 2). Bu sonuçlar, ekim dönemi geciktikçe bitkilerin daha erken bir zaman diliminde çiçeklenmeye başladıklarını göstermiştir. Bu, geç ekimlerde daha yüksek hava sıcaklığına maruz kalan bitkilerin genaratif olgunluğa daha erken bir dönemde geçmesinden kaynaklanmış olabilir. Çünkü toplam sıcaklık gereksinimlerini daha kısa zaman diliminde karşılayan bitkiler daha erken bir dönemde generatif aşamaya geçebilmektedirler (Pulvento ve ark., 2010; Tan ve Temel, 2019). Nitekim farklı ekolojilerde yapılan çalışmalarda ekim zamanına bağlı olarak çiçeklenmeye başlama zamanlarının farklılık gösterdiği ve en geç çiçeklenmenin erken dönemde yapılan ekimlerden elde edildiği rapor edilmiştir (Sayar ve ark., 2009; Geren ve Alan, 2012; Temel ve ark., 2021). Çiçeklenmeye başlama zamanları çeşitler arasında da farklılık göstermiş ve en erken çiçeklenme 73.1 gün ile Kirazlı'da, en geç çiçeklenme ise 85.7 gün ile Ürünlü çeşidinde saptanmıştır (Çizelge 2). Oluşan bu farklılıklar çeşitlerin genetik yapısına bağlı olarak erkenci veya geçci olmalarından kaynaklanmış olabilir. Nitekim aynı çeşitlerin yer aldığı farklı ekolojilerde yürütülen çalışmalarda da Kirazıı'nın erkenci, Özkaynak'ın da geçci bir çeşit olduğu rapor edilmiş (Konuk ve Tamkoç, 2018; Temel ve ark., 2021) ve bu sonuçlar mevcut araştırma bulgularıyla paralellik göstermiştir. Ayrıca ülkemizin farklı ekolojik koşullarında yürütülen çalışmalarda da çiçeklenmeye başlama zamanlarının çeşitler arasında farklıık gösterdiği ortaya konulmuştur (Seydeşoğlu, 2013; Yörük, 2016; Ömeroğlu, 2018).

Çizelge 2. Farklı dönemlerde ekilen yem bezelyesi çeşitlerinin çiçeklenmeye başlama zamanı ve bitki boyu. Table 2. The flowering time and plant height of forage pea varieties grown in different periods.

\begin{tabular}{|c|c|c|c|c|c|c|c|c|}
\hline \multirow{2}{*}{ Çeşitler (Ç) } & \multicolumn{3}{|c|}{ Çiçeklenmeye başlama zamanı (gün) } & \multirow{2}{*}{$\begin{array}{c}\text { Çeşit } \\
\text { Ortalama }\end{array}$} & \multicolumn{3}{|c|}{ Bitki boyu (cm) } & \multirow{2}{*}{$\begin{array}{c}\text { Çeşit } \\
\text { Ortalama }\end{array}$} \\
\hline & $\mathrm{ED}_{1}$ & $\mathrm{ED}_{2}$ & $\mathrm{ED}_{3}$ & & $\mathrm{ED}_{1}$ & $\mathrm{ED}_{2}$ & $\mathrm{ED}_{3}$ & \\
\hline Kirazlı & 82.0 & 73.0 & 64.3 & $73.1 d^{* *}$ & 134.3 & 102.0 & 97.4 & 111.2 \\
\hline Özkaynak & 92.7 & 81.3 & 74.3 & $82.8 \mathrm{~b}$ & 127.1 & 104.9 & 96.5 & 109.5 \\
\hline Taşkent & 88.7 & 76.7 & 69.0 & $78.1 \mathrm{c}$ & 126.6 & 103.1 & 97.5 & 109.1 \\
\hline Ürünlü & 95.7 & 84.7 & 76.7 & $85.7 \mathrm{a}$ & 131.7 & 100.2 & 90.7 & 107.5 \\
\hline ED. ortalama & $89.8 a^{\star \star}$ & $78.9 \mathrm{~b}$ & $71.1 \mathrm{c}$ & 79.9 & $129.9 \mathrm{a}^{* *}$ & $102.6 \mathrm{~b}$ & $95.5 \mathrm{c}$ & 109.3 \\
\hline LSD değeri & \multicolumn{4}{|c|}{ ED: 0.73, Ç: 0.73, ED x Ç: ö.d. } & \multicolumn{4}{|c|}{ ED: 6.72 , Ç: ö.d., ED x Ç: ö.d. } \\
\hline
\end{tabular}

**, farklı harfleri takip eden ortalamalar \%1 seviyesinde önemlidir, ö.d. önemsiz değer. ED: Ekim dönemi.

İstatistiki olarak sadece ekim zamanının önemli bulunduğu bitki boyu açısından incelendiğinde en yüksek bitki boyu $129.9 \mathrm{~cm}$ ile Nisan başında yapılan ilk ekim zamanında, en düşük boylanma ise $95.5 \mathrm{~cm}$ ile Mayıs başında yapılan son ekim döneminde tespit edilmiştir (Çizelge 2). Bu sonuçlar, ekim zamanın geçiktirilmesiyle bitki boylarında önemli düşüşlerin olduğunu göstermiştir. Bu geç ekimlerde artan hava sıcaklıklarına maruz kalan bitkilerin yeterli bir boylanma göstermeden generatif aşamaya geçmiş olmasından kaynaklanmış olabilir. Çünkü yem bezelyesi gibi serin mevsim bitkilerinde artan hava sıcaklıkları bitkilerde vejetatif gelişmeyi sona erdirmekte, generatif aşamaya geçmelerine neden olmaktadır (Tan, 2018). Nitekim farklı bölgelerde yürütülen çalışmalarda da ekim döneminin geciktirilmesiyle bitki boylarında önemli azalamların olduğu rapor edilmiştir (Kaya ark., 2003; Sarıkaya, 2019; Temel ve ark., 2021).

\section{Ana Sap Kalınlığı (mm) ve Dal Sayısı (adet bitki ${ }^{-1}$ )}

Ağrı-Eleşkirt koşullarında farklı yem bezelyesi çeşitleri ve ekim zamanlarının test edildiği bu çalışmada ana sap kalınlığı ve dal sayısına ait ortalama değerler Çizelge 3'te sunulmuştur. Ana sap kalınlığı ekim dönemleri arasında önemli farklılık göstermiş ve en yüksek sap kalınlığı son dönemde yapılan ekimde $(3.03 \mathrm{~mm})$ belirlenmiştir. Bu, geç yapılan ekimlerde artan ışık ve sıcaklık şiddetine bağlı olarak bitkilerin yeterli bir boylanma göstermeden biçim olgunluğuna gelmesinden kaynaklanmış olabilir. Çeşitler açısından değerlendirildiğinde, en yüksek sap kalınlıkları Ürünlü $(2.97 \mathrm{~mm})$, Taşkent $(2.92 \mathrm{~mm})$ ve Özkaynak $(2.91 \mathrm{~mm})$ çeşitlerinde ölçülmüş ve bu çeşitlerin sap kalınlıkları aynı istatistiki grupta yer almıştır (Çizelge 3). ığdır ekolojik koşullarında yürütülen bir çalışmada da Taşkent (2.81 $\mathrm{mm}$ ) ve Özkaynak (2.84 mm) çeşitlerinin Kirazlı $(2.42 \mathrm{~mm}$ ) çeşidinden daha yüksek bir sap kalınlığına sahip olduğu rapor edilmiş (Temel ve ark., 2021) olup, bu bulgular mevcut araştırma sonuçlarını destekler nitekliktedir. Mevcut çalışmada bitki başına dal sayısı sadece ekim dönemleri arasında önemli bulunmuştur. Buna göre en yüksek dal sayısı aynı istatistiki grupta yer alan ikinci (1.6 adet) ve üçüncü ekim (1.7 adet) zamanında, en düşük değer ise 1.3 adet ile ilk ekim döneminde belirlenmiştir (Çizelge 3). 
Temel ve Yazıcı, Ağrı-Eleşkirt Koşullarında Yazlık Olarak Farklı Zamanlarda Ekilen Yem Bezelyesi Çeşitlerinin Bazı Ot Verim ve Kalite Özelliklerinin Belirlenmesi

Çizelge 3. Farklı dönemlerde ekilen yem bezelyesi çeşitlerinin ana sap kalınlığı ve dal sayısı.

Table 3. The stem thickness and number of branches of forage pea varieties grown in different periods.

\begin{tabular}{|c|c|c|c|c|c|c|c|c|}
\hline \multirow{2}{*}{ Çeşitler (Ç) } & \multicolumn{3}{|c|}{ Ana sap kalınlığı (mm) } & \multirow{2}{*}{$\begin{array}{c}\text { Çeşit } \\
\text { Ortalama }\end{array}$} & \multicolumn{3}{|c|}{ Dal sayısı (adet bitki-1) } & \multirow{2}{*}{$\begin{array}{c}\text { Çeşit } \\
\text { Ortalama }\end{array}$} \\
\hline & $\mathrm{ED}_{1}$ & $\mathrm{ED}_{2}$ & $\mathrm{ED}_{3}$ & & $\mathrm{ED}_{1}$ & $\mathrm{ED}_{2}$ & $\mathrm{ED}_{3}$ & \\
\hline Kirazlı & 2.64 & 2.56 & 2.91 & $2.71 b^{\star \star}$ & 1.3 & 1.5 & 1.7 & 1.5 \\
\hline Özkaynak & 2.91 & 2.82 & 2.99 & $2.91 \mathrm{a}$ & 1.5 & 1.7 & 1.6 & 1.6 \\
\hline Taşkent & 3.04 & 2.76 & 2.96 & $2.92 \mathrm{a}$ & 1.4 & 1.6 & 1.6 & 1.6 \\
\hline Ürünlü & 2.93 & 2.73 & 3.26 & $2.97 \mathrm{a}$ & 1.2 & 1.5 & 1.7 & 1.5 \\
\hline ED. ortalama & $2.88 a b^{*}$ & $2.72 \mathrm{~b}$ & $3.03 \mathrm{a}$ & 2.88 & $1.3 b^{* *}$ & $1.6 \mathrm{a}$ & $1.7 \mathrm{a}$ & 1.6 \\
\hline LSD değeri & \multicolumn{4}{|c|}{ ED: 0.22 , Ç: $0.12, E Z$ x Ç: ö.d. } & \multicolumn{3}{|c|}{ ED: 0.09, Ç: ö.d., EZ x Ç: ö.d. } & \\
\hline
\end{tabular}

${ }^{* *}$ ve *, farklı harfleri takip eden ortalamalar sırasıyla \%1 ve \%5 seviyesinde önemlidir, ö.d. önemsiz değer. ED: Ekim dönemi.

Bu sonuçlar ekim döneminin geçiktirilmesiyle bitki başına dallanmanın daha fazla oluştuğunu göstermiştir. Nitekim Van koşullarında yem bezelyesi ile yürütülen bir çalışmada son dönemde yapılan ekimlerin erken dönemde yapılan ekimlere göre daha fazla dal sayına sahip oldukları rapor edilmiştir (Gündoğdu, 2006).

\section{Yaş Ot Verimi $\left(\mathrm{kg} \mathrm{da}^{-1}\right)$ ve Kuru Ot Verimi $\left(\mathrm{kg} \mathrm{da}^{-1}\right)$}

Ağrı-Eleşkirt koşullarında farklı zamanlarda ekilen yem bezelyesi çeşitlerinin yaş ot ve kuru ot verimlerine ait önemlilik düzeyleri, LSD ve ortalama değerler Çizelge 4'te sunulmuştur. Ekim dönemlerine bağlı olarak elde edilen yaş ot verimleri $1026.2-2053.1 \mathrm{~kg} \mathrm{da}^{-1}$, kuru ot verimleri ise $204.4-398.2 \mathrm{~kg} \mathrm{da}^{-1}$ arasında değişim göstermiştir (Çizelge 2). Mevcut bu sonuçlar ekim zamanı geciktikçe yaş ve kuru ot verimlerin önemli oranda düştüğünü göstermiştir. Bu, erken dönemde yapılan ekimlere göre geç tarihte yapılan ekimlerde bitkilerin ortam koşulları ve kültürel uygulamalardan daha az istifade etmesinden kaynaklanmış olabilir. Nitekim benzer sonuçlar farklı ekolojik koşullarda yürütülen çalışmalarda da ortaya konmuş ve ekim zamanının geciktirilmesiyle bitkilerin yaş ot ve kuru ot verimlerinde önemli kayıpların yaşandığı rapor edilmiştir (Sarıkaya, 2019; Temel ve ark., 2021). Ayrıca ekim dönemlerine bağlı olarak yaş ot verimlerinde önemli farklılıklar görüldüğü öncesinde yürütülen çalışmalar tarafından da ortaya konmuştur (Kaya ve ark., 2003, Düzdemir ve ark., 2004). Çeşitler açısından değerlendirildiğinde en düşük yaş ot $\left(1231.7 \mathrm{~kg} \mathrm{da}^{-1}\right)$ ve kuru ot $\left(239.5 \mathrm{~kg} \mathrm{da}^{-1}\right)$ verimleri Özkaynak çeşidinde belirlenirken, en yüksek yaş ot verimi Taşkent $\left(1792.7 \mathrm{~kg} \mathrm{da}^{-1}\right)^{\prime}$ te, kuru ot verimi ise aynı istatistiki grupta yer alan Ürünlü (319.1 kg da-1) ve Taşkent (317.7 kg da $\left.{ }^{-1}\right)$ çeşitlerinde belirlenmiştir (Çizelge 4).

Çizelge 4. Farklı dönemlerde ekilen yem bezelyesi çeşitlerinin yaş ot ve kuru ot verimleri.

Table 4. The fresh and dry hay yields of forage pea varieties grown in different periods.

\begin{tabular}{|c|c|c|c|c|c|c|c|c|}
\hline \multirow{2}{*}{ Çeşitler (Ç) } & \multicolumn{3}{|c|}{ Yaş ot verimi $\left(\mathrm{kg} \mathrm{da}^{-1}\right)$} & \multirow{2}{*}{$\begin{array}{c}\text { Çeşit } \\
\text { Ortalama }\end{array}$} & \multicolumn{3}{|c|}{ Kuru ot verimi $\left(\mathrm{kg} \mathrm{da}^{-1}\right)$} & \multirow{2}{*}{$\begin{array}{c}\text { Çeşit } \\
\text { Ortalama }\end{array}$} \\
\hline & $\mathrm{ED}_{1}$ & $\mathrm{ED}_{2}$ & $\mathrm{ED}_{3}$ & & $\mathrm{ED}_{1}$ & $\mathrm{ED}_{2}$ & $\mathrm{ED}_{3}$ & \\
\hline Kirazlı & 1771.4 & 1276.2 & 981.0 & $1342.9 c^{* *}$ & 369.3 & 261.5 & 202.4 & $277.7 b^{\star *}$ \\
\hline Özkaynak & 1600.0 & 1104.8 & 990.5 & $1231.7 \mathrm{~d}$ & 319.0 & 207.0 & 192.5 & $239.5 \mathrm{c}$ \\
\hline Taşkent & 2540.0 & 1714.3 & 1123.8 & 1792.7 a & 458.7 & 274.1 & 220.4 & 317.7 a \\
\hline Ürünlü & 2301.0 & 1580.9 & 1009.5 & $1630.5 \mathrm{~b}$ & 445.7 & 309.4 & 202.2 & $319.1 \mathrm{a}$ \\
\hline ED. ortalama & $2053.1 a^{* *}$ & $1419.0 \mathrm{~b}$ & $1026.2 \mathrm{c}$ & 1499.4 & $398.2 a^{* *}$ & $263.0 \mathrm{~b}$ & $204.4 \mathrm{c}$ & 288.5 \\
\hline LSD değeri & \multicolumn{4}{|c|}{ ED: 61.42, Ç: 104.46 , ED x Ç: 180.92} & \multicolumn{3}{|c|}{ ED: 38.05, Ç: 23.97, ED x Ç: 41.53} & \\
\hline
\end{tabular}

**, farklı harfleri takip eden ortalamalar \%1 seviyesinde önemlidir. ED: Ekim dönemi

Çeşitlerin farklı genetik yapıya sahip olmaları buna neden olmuş olabilir. Öncesinde farklı ekolojik koşullarda yürütülen araştırmalarda da yaş ot (1156.13-4057.2 kg da-1) ve kuru ot (189.6-1190.3 kg da-1) verimlerinin çeşitler arasında önemli farklılıklar gösterdiği rapor edilmiştir (Tekeli ve Ates, 2003; Timurağaoğlu ve ark., 2004, Bilgili ve ark., 2007; Sayar ve ark., 2009; Geren ve Alan, 2012; Uzun ve ark., 2012; Seydoşoğlu, 2013; Kavut ve ark., 2016; Yörük, 2016; Konuk ve Tamkoç, 2018; Temel ve ark., 2021). Çeşitler arasında oluşan bu farklılıkların araştırmanın yapıldığı bölgenin ekolojik koşullarından, kültürel uygulamalardan ve çeşitlerin farklı genetik yapıya sahip olmalarından kaynaklandığı düşünülmektedir.

Ekim zamanı $x$ çeşit interaksiyonu açısından yaş ot ve kuru ot verimleri istatistiki olarak önemli farklılık göstermiş̧ir. Buna göre en yüksek yaş ot verimi ilk dönemde ekimi yapılan Taşkent $\left(2540.0 \mathrm{~kg} \mathrm{da}^{-1}\right)$ çeşidinde (Şekil 1a), en yüksek kuru ot verimi ise erken dönemde ekimi yapılan Taşkent (458.7 kg da-1) ve Ürünlü (445.7 kg $\mathrm{da}^{-1}$ ) çeşitlerinde (Şekil 1b) alınmıştır. İkinci ekim dönemine göre üçüncü ekim zamanında Özkaynak ve Kirazlı çeşitlerine ait yaş ot verimlerinin diğer iki çeşide göre daha düşük bir oranda azalma göstermesi yaş ot verimi açısından ikili interaksiyonun önemli çıkmasına neden olmuş olabilir. Kuru ot verimi açısından ise, birinci ekim zamanına göre ikinci ekim döneminde Taşkent çeşidinin diğer çeşitlere göre daha yüksek oranda düşüş 
Temel ve Yazıcı, Ağrı-Eleşkirt Koşullarında Yazlık Olarak Farklı Zamanlarda Ekilen Yem Bezelyesi Çeşitlerinin Bazı Ot Verim ve Kalite Özelliklerinin Belirlenmesi

göstermesi ve ikinci ekim dönemine göre de üçüncü ekim zamanında Özkaynak çeşidinin diğer çeşitlere göre daha düşük bir oranda azalma göstermesi ekim dönemi x çeşit interaksiyonun önemli çıkmasına neden olmuş olabilir. Dolayısıyla çeşitlerin ekim zamanlarına göre farklı tepki göstermesi yaş ot ve kuru verimlerinin önemli çıkmasına neden olmuştur.



**, farklı harfleri takip eden çizimler \%1 seviyesinde önemlidir.

Şekil 1. Yaş ot (a) ve kuru ot verimi (b) üzerine ekim dönemi $x$ çeşit interaksiyonunun etkisi.

Figure 1. The effect of sowing period $x$ variety interaction on the fresh herbage (a) and dry herbage yield (b).

\section{Kuru Madde Oranı (\%) ve Ham Protein Oranı (\%)}

Farklı zamanlarda ekimi yapılan yem bezelyesi çeşitlerinin ortalama kuru madde ve ham protein oranları Çizelge 5 'de verilmiştir. Çizelge 5 incelendiğinde kuru madde oranı sadece çeşitler açısından önemli bulunmuş ve en yüksek kuru madde oranı \%20.70 ile Kirazlı'da, en düşük değer ise Taşkent çeşidinde belirlenmiştir. Farklı ekolojik koşullarda aynı çeşitlerle yürütülen çalışmalarda da Kirazlı çeşidinin daha yüksek, Taşkent çeşidinin ise daha düşük kuru madde oranına sahip olduğu bulunmuştur (Kavut ve ark., 2016; Temel ve ark., 2021). Ayrıca Türkiye'nin farklı bölgerinde yapılan araştırma sonuçlarında kuru madde oranlarının çeşitler arasında farklılık gösterdiği ortaya konmuştur (Açıkgöz ve ark., 2007; Bilgili ve ark., 2007; Geren ve Alan, 2012).

Çizelge 5. Farklı dönemlerde ekilen yem bezelyesi çeşitlerinin kuru ot ve ham protein oranı. Table 5. The dry matter and crude protein ratio of forage pea varieties grown in different periods.

\begin{tabular}{|c|c|c|c|c|c|c|c|c|}
\hline \multirow{2}{*}{ Çeşitler (Ç) } & \multicolumn{3}{|c|}{ Kuru ot oranı (\%) } & \multirow{2}{*}{$\begin{array}{c}\text { Çeşit } \\
\text { Ortalama }\end{array}$} & \multicolumn{3}{|c|}{ Ham protein oranı (\%) } & \multirow{2}{*}{$\begin{array}{c}\text { Çeşit } \\
\text { Ortalama }\end{array}$} \\
\hline & $\mathrm{ED}_{1}$ & $\mathrm{ED}_{2}$ & $\mathrm{ED}_{3}$ & & $\mathrm{ED}_{1}$ & $\mathrm{ED}_{2}$ & $\mathrm{ED}_{3}$ & \\
\hline Kirazlı & 20.97 & 20.57 & 20.57 & $20.70 a^{* *}$ & 20.19 & 19.48 & 16.53 & $18.73 b^{*}$ \\
\hline Özkaynak & 19.93 & 18.73 & 19.53 & $19.40 \mathrm{~b}$ & 21.74 & 21.43 & 20.78 & $21.32 \mathrm{a}$ \\
\hline Taşkent & 18.00 & 15.97 & 19.63 & $17.87 \mathrm{c}$ & 21.20 & 18.94 & 18.22 & $19.45 \mathrm{~b}$ \\
\hline Ürünlü & 19.37 & 19.50 & 19.97 & $19.61 \mathrm{~b}$ & 21.39 & 19.77 & 19.57 & $20.24 a b$ \\
\hline ED. ortalama & 19.57 & 18.69 & 19.93 & 19.39 & $21.13 a^{* *}$ & $19.90 \mathrm{~b}$ & $18.77 \mathrm{c}$ & 19.94 \\
\hline LSD değeri & \multicolumn{4}{|c|}{ ED: ö.d., Ç: 1.04, ED x Ç: ö.d. } & \multicolumn{4}{|c|}{ ED: 0.53 , Ç: 1.72 , ED x Ç: ö.d. } \\
\hline
\end{tabular}

** ve *, farklı harfleri takip eden ortalamalar sırasıyla \%1 ve \%5 seviyesinde önemlidir, ö.d. önemsiz değer. ED: Ekim dönemi.

Mevcut çalışmada ham protein oranı ekim dönemleri ve çeşitler arasında önemli farklılıklar göstermiştir (Çizelge 5). Ekim dönemleri açısından değerlendirildiğinde ekim zamanının geçiktirilmesiyle yem örneklerinin ham protein içeriğinin azaldığı görülmüştür. Buna göre en yüksek ve en düşük ham protein oranları sırasıyla ilk ve son ekim döneminde belirlenmiştir (Çizelge 5). Bu, erken dönemde yapılan ekimde dal sayısı ve ana sap kalınlığının diğer ekim dönemlerine göre daha düşük olmasından kaynaklanmış olabilir (Çizelge 3). Çünkü yem materyali olarak tercih edilen bitkilerde düşük dal sayısı ve sap kalınlığı yaprak/sap oranını arttırmakta, bu da yemin ham protein içeriğinin yüksek olmasına neden olmaktadır (Sarıkaya, 2019). Nitekim yaprak kısımları hücre içi maddeler (nişasta, şeker, protein ve yağ) yönünden saplara göre daha zengindirler (Önal Aşcı ve Acar, 2018). Konu ile ilgili olarak öncesinde yapılan araştırmalarda da ekim zamanı geciktikçe bitkilerin ham protein oranlarının azaldığı ifade edilmiştir (Tekeli ve Ateş, 2007; Türk ve ark., 2007; Temel ve ark., 2021). Çeşitler açısından incelendiğinde, çeşitlerin ham protein içerikleri \%18.73 ile \%21.32 arasında değişim göstermiş ve Özkaynak çeşidi \%21.32 ile diğer çeşitlerden daha yüksek bir ham protein içeriğine sahip olduğu görülmüştür (Çizelge 5). Bu, çeşitlerin farklı genetik yapıya ve doku organizasyonuna sahip olmalarından kaynaklamış olabilir. Iğdır koşullarında yürütülen bir çalışmada da Taşkent çeşidi ile aynı istatistiki grupta yer alan Özkaynak çeşidi en yüksek, Kirazlı ise en düşük ham protein oranına sahip olduğu rapor edilmiş (Temel ve ark., 2021) ve bu sonuçlar bizim araştırma bulgularımızla paralellik göstermiştir. Ayrıca Türkiye'nin farklı ekolojik koşullarında yürütülen araştırmalarda da ham protein 
Temel ve Yazıcı, Ağrı-Eleşkirt Koşullarında Yazlık Olarak Farklı Zamanlarda Ekilen Yem Bezelyesi Çeşitlerinin Bazı Ot Verim ve Kalite Özelliklerinin Belirlenmesi

oranının çeşitler arasında farklılık gösterdiği ifade edilmiştir (Tekeli ve Ateş, 2007; Uzun ve Aşık, 2009; Uzun ve ark., 2012; Ömeroğlu, 2016).

\section{Nötr Çözücülerde Çözünemeyen Lif Oranı (\%) ve Asit Çözücülerde Çözünemeyen Lif Oranı (\%)}

Ağrı-Eleşkirt koşullarında farklı yem bezelyesi çeşitleri ve ekim dönemlerinin test edildiği mecut çalışmada, nötr çözücülerde çözünemeyen lif (NDF) ve asit çözücülerde çözünemeyen lif (ADF) oranı üzerine sadece ekim zamanlarının etkisi istatistiki olarak önemli bulunmuştur (Çizelge 6). Çizelge 6 incelendiğinde, ekim dönemleri geçiktirildikçe yemlerin NDF ve ADF içeriklerinin arttığı ve en düşük oranların ise ilk ekim zamanında belirlendiği görülmüştür. Bu, ilk ekim zamanlarına göre son dönemde yapılan ekimlerde dal sayısı ve ana sap kalınlığının daha yüksek olmasından kaynaklanmış olabilir (Çizelge 3). Çünkü bitki sapları yaprağa göre daha fazla miktarda selüloz, hemiselüloz ve lignin gibi hücre dışı maddeler içermektedir (Önal Aşcı ve Acar, 2018).

Çizelge 6. Farklı dönemlerde ekilen yem bezelyesi çeşitlerinin nötr ve asit çözücülerde çözünemeyen lif (NDF ve ADF) oranı. Table 6. The neutral and acid detergent fiber ratio (NDF and ADF) of forage pea varieties grown in different periods.

\begin{tabular}{|c|c|c|c|c|c|c|c|c|}
\hline \multirow{2}{*}{ Çeşitler (Ç) } & \multicolumn{3}{|c|}{ NDF oranı (\%) } & \multirow{2}{*}{$\begin{array}{c}\text { Çeşit } \\
\text { Ortalama }\end{array}$} & \multicolumn{3}{|c|}{ ADF oranı (\%) } & \multirow{2}{*}{$\begin{array}{c}\text { Çeşit } \\
\text { Ortalama }\end{array}$} \\
\hline & $\mathrm{ED}_{1}$ & $\mathrm{ED}_{2}$ & $\mathrm{ED}_{3}$ & & $\mathrm{ED}_{1}$ & $\mathrm{ED}_{2}$ & $\mathrm{ED}_{3}$ & \\
\hline Kirazlı & 41.07 & 45.67 & 45.76 & 44.17 & 31.69 & 31.75 & 32.83 & 32.09 \\
\hline Özkaynak & 41.84 & 44.61 & 46.51 & 44.32 & 30.23 & 33.05 & 35.74 & 33.01 \\
\hline Taşkent & 41.66 & 41.50 & 44.59 & 42.59 & 32.89 & 33.67 & 35.56 & 34.04 \\
\hline Ürünlü & 42.37 & 44.02 & 47.44 & 44.61 & 34.55 & 36.08 & 36.33 & 35.65 \\
\hline ED. ortalama & $41.74 c^{* *}$ & $43.95 \mathrm{~b}$ & $46.08 \mathrm{a}$ & 43.92 & $32.34 c^{* *}$ & $33.64 \mathrm{~b}$ & $35.11 \mathrm{a}$ & 33.70 \\
\hline
\end{tabular}

LSD değeri ED: 1.81, Ç: ö.d., ED x Ç: ö.d. ED: 1.28, Ç: ö.d., ED x Ç: ö.d.

**, farklı harfleri takip eden ortalamalar \%1 seviyesinde önemlidir, ö.d. önemsiz değer. ED: Ekim dönemi

\section{SONUÇ}

Karasal iklim özelliğine sahip Ağrı-Eleşkirt koşullarına uygun yem bezelyesi çeşitleri ve ekim zamanlarının test edildiği bu çalışmada; ekim zamanlarına göre çeşitlerin çiçeklenmeye başlama gün sayısı 71.1-89.8, sap kalınlığı 2.71-2.97, bitki boyu 107.5-111.2 cm, dal sayısı 1.5-1.6 adet, yaş ot verimi $1231.7-1792.7 \mathrm{~kg} \mathrm{da}^{-1}$, kuru madde oranı \%19.40-20.70, kuru ot verimi 277.7-319.1 kg da-1, ham protein oranı \%18.73-21.32, ADF oranı \%32.09-35.65 ve NDF oranı \%41.74-46.08 arasında değişim göstermiştir. İncelenen verim özellikleri açısından Taşkent ve Ürünlü, kalite özellikleri açısından ise Özkaynak ve Ürünlü çeşitleri ilk sırada yer almıştır. Ayrıca Nisan başında yapılan ilk ekim döneminde elde edilen otun verim ve kalitesi en yüksek seviyede bulunmuş ve ekim zamanı geciktirildikçe otun verim ve kalitesinde önemli düşüşlerin yaşandığı belirlenmiştir. Sonuç olarak bölgede yüksek verim ve kalitede bir kaba yem üretimi için Ürünlü ve Taşkent çeşitlerinin uygun olduğu ve yazlık ekimlerin ilk fırsatta yapılması gerektiği sonucuna varılmıştır.

\section{TEŞEKKÜR}

Bu çalışma Iğdır Üniversitesi Bilimsel Araştırma Projeleri Koordinasyon Birimi tarafından desteklenmiştir. 2019FBE-L03 no.lu projeye sağlamış oldukları finansman desteklerinden dolayı BAP birimine teşekkür ederiz.

\section{ÇIKAR ÇATIŞMASI}

Makale yazarları arasında herhangi bir çıkar çatışması bulunmamaktadır.

\section{YAZAR KATKISI}

Yazarlar makaleye eşit oranda katkı sağlamışlardır.

\section{KAYNAKLAR}

Açıkgöz, E., Üstün, A., Gül, İ., Anlarsal, E., Tekeli, A. S. , Nizam, I., Avcıoğlu, R., Geren, H., Çakmakçı, S., Aydınoğlu, B., Yücel, C., Avcl, M., Acar, Z., Ayan, I., Uzun, A., Bilgili, U., Sincik, M., \& Yavuz, M. (2007). Yem bezelyesi (Pisum sativum L.)'inde genotip $x$ çevre ilişkileri ve kuru madde ile tohum veriminde stabilite analizleri. Türkiye 7. Tarla Bitkileri Kongresi, Erzurum.

Alatürk, F., Çınar, Ç., \& Gökkuş, A. (2021). Farklı sıra aralıklarının bazı yem bezelyesi çeşitlerinin verim ve kalitesi üzerine etkileri. Türk Tarım ve Doğa Bilimleri Dergisi, 8, 53-57. 
AOAC. (1997). Official Methods of Analysis. Association of Official Analytical Chemists. 16. Ed. 3. Revision. Arlington, VA, USA.

Ateş, E., \& Tekeli, A. S. (2017). Farklı taban gübresi uygulamalarının yem bezelyesi (Pisum arvense L.)'nin ot verimi ve kalitesine etkisi. Kahramanmaraş Sütçü Imam Üniversitesi Doğa Bilimleri Dergisi, 20, 13-16.

Bilgili, U., Uzun, A., Sincik, M., Yavuz, M., Açıkgöz, E., Üstün, A., Gül, İ., Anlarsal, E., Tekeli, A.S., Nizam, I.., Avcıoğlu, R., Geren, H., Çakmakçı, S., Aydınoğlu, B., Yücel, C., Avcı, M., Acar, Z., \& Ayan, İ. (2007). Farklı yaprak tiplerindeki yemlik bezelye hatlarının verim ve bazı verim özelliklerinin belirlenmesi. Türkiye 7. Tarla Bitkileri Kongresi, Erzurum.

Çil, A. N., Çil, A., Yücel, C., \& Açıkgöz, E. (2007). Harran ovası koşullarında bazı bezelye (Pisum sativum L.) hatlarının verim ve verim özellikleri. Türkiye 7. Tarla Bitkileri Kongresi, Erzurum.

Düzdemir, O., Ece, A., Akdağ, C., \& Uysal, F. (2004). Bezelyede kışlık ve yazlık yetiştirilme olanaklarının belirlenmesi. V. Sebze Tarımı Sempozyumu, Çanakkale.

Geren, H., \& Alan, Ö. (2012). Farklı ekim zamanlarının iki bezelye (Pisum sativum L.) çeşidinde ot verimi ve diğer bazı özellikler üzerine etkileri. Anadolu Dergisi, 22, 37-47.

Göçmen, N., \& Özaslan Parlak, A. (2017). Yem bezelyesi ile arpa, yulaf ve Tritikale karışım oranlarının belirlenmesi. ÇOMÜ Ziraat Fakültesi Dergisi, 5, 119-124.

Gündoğdu, Y. (2006). Farklı ekim zamanı uygulamaların bezelye (Pisum sativum ssp. arvense L.)'de verim ve verim öğelerin etkisi. Yüksek Lisans Tezi, Yüzüncü Yıl Üniversitesi, Fen Bilimleri Enstitüsü, Van.

Kacar, B. (2012). Toprak Analizleri. Nobel Akademik Yayıncılık, Yayın No: 484, Ankara.

Kadıoğlu, S., \& Tan, M. (2018). Erzurum şartlarında farklı tarihlerde kışıı ekilen yem bezelyesi çeşitlerinin verim ve bazı özellikleri. Tarla Bitkileri Merkez Araştırma Enstitüsü Dergisi, 27, 25-32.

Kavut, Y. T., Çelen, A. E., Çıbık, Ş. E., \& Urtekin, M. A. (2016). Ege Bölgesi koşullarında farklı sıra arası mesafelerinde yetiştirilen bazı yem bezelyesi (Pisum arvense L.) çeşitlerinin verim ve diğer bazı özellikleri üzerine bir araştırma. Tarla Bitkileri Merkez Araştırma Enstitüsü Dergisi, 25, 225-229.

Kaya, M., Çiftçi, C. Y., Atak, M., \& Kaya, M.D. (2003). Winner bezelye (Pisum sativum L.) çeşidinde farklı aşılama yöntemleri azotlu gübre dozları ile ekim zamanlarının verim ve bazı özellikler üzerine etkileri. Türkiye 5. Tarla Bitkileri Kongresi, Diyarbakır.

Keskin, B., Temel, S., \& Eren, B., 2021. Farklı zamanlarda ekilen bazı yem bezelyesi (Pisum sativum ssp. arvense L.) çeşitlerinin tohum ve kesinin besin değerleri. Uluslararası Tarım ve Yaban Hayatı Bilimleri Dergisi, 7, 96-105.

Konuk, A., \& Tamkoç, A. (2018). Yem bezelyesinde kışlık ve yazlık ekimin bazı tarımsal özellikler üzerine etkisi. Bahri Dağdaş Bitkisel Araştırma Dergisi, 7, 39-50.

MGM. (2019). Başbakanlık DMi Genel Müdürlüğü Meteroloji Bültenleri, Ankara

Mukherjee, D., Sharma, B. R., \& Mani, J. K. (2013). Influence of different sowing dates and cultivars on growth, yield and disease Incidence in garden pea (Pisum sativum) under Mid Hill Stuation. Indian Journal of Agricultural Sciences, 83, 918-923.

Ömeroğlu, E. (2016). Isparta koşullarında bazı yem bezelyesi (Pisum arvense L.) çeşitlerinin ot ve tohum verimleri ile bazı verim ögelerinin belirlenmesi üzerine bir araştırma. Yüksek Lisans Tezi, Süleyman Demirel Üniversitesi, Fen Bilimleri Enstitüsü, Isparta.

Önal Aşcı, Ö., \& Acar, Z. (2018). Kaba Yemlerde Kalite. Pozitif Matbaacılık ve Ambalaj Sanayi Ticaret Limited Şirketi, Ankara.

Pulvento, C., Riccardi, M., Lavini, A., D'Andria, R., Lafelice, G., \& Marconi, E. (2010). Field trial evaluation of two Chenopodium quinoa genotypes grown under rain-fed conditions in a typical Mediterranean environment in South Italy. Journal of Agronomy and Crop Science, 196, 407-411.

Sarıçiçek, B. Z. (1995). Yemler Bilgisi Laboratuvar Kılavuzu. Ondokuz Mayıs Üniversitesi Ziraat Fakültesi Ders Notu No:16, Samsun.

Sarıkaya, M. F. (2019). Eskişehir ovasında ekim zamanı ve bitki sıklığının yem bezelyesinin ot verimi üzerine bir araştırma. Yüksek Lisans Tezi, Eskişehir Osmangazi Üniversitesi, Fen Bilimleri Enstitüsü, Eskişehir.

Sayar, M. S., Anlarsal, A. E., Açıkgöz, E., Başbağ, M., \& Gül, İ. (2009). Diyarbakır koşullarında bazı yem bezelyesi (P. arvense L.) hatlarının verim ve verim unsurlarının belirlenmesi. Türkiye VIII. Tarla Bitkileri Kongresi, Hatay.

Seydoşoğlu, S. (2013). Diyarbakır ekolojik koşullarında bazı yem bezelyesi (Pisum sativum L.) genotiplerinin verim ve verim unsurları. Uludağ Üniversitesi Ziraat Fakültesi Dergisi, 13, 121-131.

Shaukat, S. A., Ahmad, Z., Chodry, Y. A., \& Shaukat, S. K. (2012). Effect of different sowing dates and row spacing on then growth, seed yield and quality of off-season pea (Pisum sativum L. CV. Climax) under temperate conditions of Rawalakot Azad Jammu and Kashmir. Scientific Journal of Agricultural, 1, 117-125. 
Sheaffer, C. C., \& Moncada, K. M. (2012). Introduction to Agronomy-Food, Crops and Environment. $2^{\text {nd }}$ Ed. Delmar, Clifton Park, NY.

Tan, M. (2018). Baklagil ve Buğdaygil Yem Bitkileri. Erzurum Atatürk Üniversitesi, Ziraat Fakültesi, Ders Yayınları No: 256, Erzurum.

Tan, M., Koç, A., Dumlu Gül, Z., Elkoca, E., \& Gül, I. (2013). Determination of dry matter yield and yield component of local forage pea (Pisum sativum ssp. arvense L.) ecotypes. Tarım Bilimleri Dergisi, 19, 289-296.

Tan, M., \& Temel, S. (2012). Alternatif Yem Bitkileri. Atatürk Üniversitesi, Ziraat Fakültesi, Ders Yayınları No: 246, Erzurum.

Tan, M., \& Temel, S. (2019). Her Yöneyle Kinoa, Önemi, Kullanılması ve Yetiştiriciliği. Iksad Publishing House, Ankara.

Tekeli, A. S., \& Ateş, E. (2003). Yield and its components in field pea (Pisum arvense L.) Lines. Journal of Central European Agriculture, 4, 313-317.

Tekeli, A. S., \& Ateş, E. (2007). Farklı biçim dönemlerinin yem bezelyesi (Pisum arvense L.)-buğday (Triticum aestivum L.) karışımının yem verimi ve kalitesi ile tetani oranına etkileri. Türkiye VII. Tarla Bitkileri Kongresi, Erzurum.

Temel, S., Keskin, B., Tosun, R., \& Çakmakçı, S., 2021. Yazlık olarak ekilen yem bezelyesi çeşitlerinde ot verim ve kalite performanslarının belirlenmesi. Türk Tarım ve Doğa Bilimleri Dergisi, 8(2), 411-419.

Timurağaoğlu, K. A., Genç, A., \& Altınok, S. (2004). Ankara koşullarında yem bezelyesi hatlarında yem ve tane verimleri. Tarım Bilimleri Dergisi, 10, 457-461.

Ton, A. (2013). Çukurova koşullarında farklı ekim zamanlarının bazı bezelye (Pisum sativum ssp. sativum L.) çeşitlerinde verim ve verim öğelerine etkisi üzerine bir araştırma. Yüksek Lisans Tezi, Çukurova Üniversitesi, Fen Bilimleri Enstitüsü, Adana.

TÜiK. (2020). Türkiye İstatistik Kurumu. https://data.tuik.gov.tr/Bulten/Index?p=Bitkisel-Uretim-Istatistikleri-2018-27635. Erişim tarihi: 06 Nisan 2021.

TÜiK. (2021). Türkiye İstatistik Kurumu. https://biruni.tuik.gov.tr/medas/?kn=92\&locale=tr. Erişim tarihi: 20 Nisan 2021.

Türk, M., Albayrak, S., \& Yüksel, O. (2007). Effectes of phophorus fertilization and harvesting stages on forage yield and quality of narbon vetch. New Zealand Journal Agricucltere. Research, 50, 457-462.

Uzun, A., \& Aşık, F. F. (2009). Bezelye+yulaf karışımında farkı karışım oranları ile biçim zamanlarının otun verimi ve kalitesi üzerine etkisi. Türkiye VIII. Tarla Bitkileri Kongresi, Hatay.

Uzun, A., Gün, H., \& Açıkgöz, E. (2012). Farklı gelişme dönemlerinde biçilen bazı yem bezelyesi çeşitlerinin ot, tohum ve ham protein verimlerinin belirlenmesi. Uludağ Üniversitesi Ziraat Fakültesi Dergisi, 26, 27-38.

Van Soest, P. J., Robertson, J. D., \& Lewis, B. A. (1991). Methods for diatery fibre, neutral detergent fibre and non-starch polysaccharides in relation to animals nutrition. Journal of Dairy Science, 74, 3583-3597.

Yörük, V. (2016). Sivas ekolojik koşullarında bazı yem bezelyesi genotiplerinin agro morfolojik özelliklerinin ve külleme hastalığına (Erysiphe polygoni) karşı reaksiyonları. Yüksek Lisans Tezi, Gaziosmanpaşa Üniversitesi, Fen Bilimleri Enstitüsü, Tokat. 